\begin{tabular}{|c|c|c|c|c|c|c|c|c|}
\hline$n$ & $q^{n}$ & $d_{n}$ & $\mathrm{C}_{n}$ & $\mathrm{C}_{-n}$ & $\mathbf{F}_{n}$ & $\left(\begin{array}{c}F_{-n} \\
\left(=1-F_{n}\right)\end{array}\right.$ & $\mathrm{G}_{n}$ & $\mathrm{G}_{-n}$ \\
\hline $\begin{array}{l}1 \\
2 \\
3 \\
4 \\
5\end{array}$ & $\begin{array}{l}1 \cdot 089023 \\
1 \cdot 185971 \\
1 \cdot 291550 \\
1 \cdot 406527 \\
1 \cdot 531740\end{array}$ & $\begin{array}{r}\cdot 511 \\
1 \cdot 043 \\
1 \cdot 596 \\
2 \cdot 170 \\
2765\end{array}$ & $\begin{array}{r}0006299 \\
-0013158 \\
-0020628 \\
-0028763 \\
-0037623\end{array}$ & 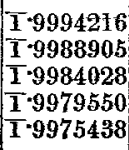 & $\begin{array}{r}4786927 \\
4574626 \\
4363858 \\
4155366 \\
-3949853\end{array}$ & $\begin{array}{l}-5213073 \\
-5425374 \\
5636142 \\
55844634 \\
6050147\end{array}$ & 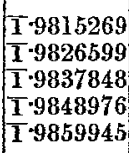 & 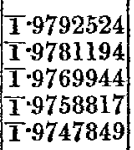 \\
\hline
\end{tabular}

\title{
ON THE SUPERANNUATION OF EMPLOYÉS IN ASSURANCE OFFICES.
}

\section{To the Editor of the Assurance Magazine.}

Sin,-May I solicit the favonr of your allotting a small space in your Journal for the insertion of a few remarks upon the subject of snperannnation of employés in Assarance Offices, in the hope that it may engage the attention that it certainly deserves, but which, I believe, it has not hitherto received.

There may be, and, no donbt, are, systems of superannuation in connexion with some of our public institutions, but they are not, I believe, general; indeed, I am only aware of one instance in which a scheme exists in connexion with a Joint Stock Company for granting retiring pensions after certain periods of service. The Company referred to is the National Provincial Bank of England, and the main features of the scheme are, the option of retirement, after 20 years' service, on one-third of salary; after 30 years, on half salary; or, after 40 years, on two-thirds salary; and in proportion for intermediate periods of service-one of the conditions being, that the age of 60 shall be attained before retiring.

It will be seen that there is here no inducement held out to withdraw from active duties, but there is an option given of doing so, that wonld be esteemed a boon by very many who yet might never avail themselves of it.

Habit, we all know, has a powerful hold upon men generally-probably upon no class is its influence greater than upon those engaged in official routine-and it may reasonably be supposed that few men would, if in health, readily sacrifice two-thirds, or a half, of their income, merely for the sake of living in idleness.

It may be suggested, that a person has no claim apon the Company by which he has been employed-whatever may have been the length of his services-when incapacitated, by sickness or other infirmity, for further duty; true, he has no legal elaim, but I am happy to think that boards of directors of Assurance Companies are not usually composed of men who take this view of things.

Assuming, then, a willingness to entertain the question of superannuation, a difficulty may arise respecting the cost; this is, however, rather imaginary than real, as $I$ hope to show.

Waiving the consideration of retiring pensions to heads of departments, I will take the general staff of an Office, and assume that all engagements

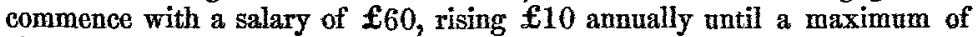
$£ 250$ is reached, which would be in 20 years. Supposing, then, an individual who has attained the age of 60 , and has been engaged in the service of a Company for 30 years, shonld feel desirous to retire from the cares and 
responsibilities that have for so long a period devolved upon him, what would be the pecuniary effect upon a Company, of allowing him to do so with a pension of $£ 125$ per annum, and appointing a junior to fill up the vacancy that would be caused? The cost of a Goverument annuity may be considered to be a fair basis upon which to form an estimate, and this, at the age of 60 , would amount to about $£ 1,300$, against which has to be placed the present value of the anmual differences between the salary paid to the newly appointed clerk and that which would have been payable had no change taken place; this will amount to about $£ 1,500$, and the result would be an actual gain to the Company of $£ 200$ in the 20 years that would elapse before the maximum salary of $£ 250$ would be attained.

True, it may be said that a person of 60 years of age is not likely to remain at his post another 20 years; but there is also the contingency of a junior not continuing 20 years. Indeed, I believe that the average length of time is likely to be as great in the former as in the latter ease.

Did space permit, very many arguments might be adduced in favour of thus making provision for the retirement of officials of long standing; and I am not aware that any objections against it can be raised. However, I offer these few suggestions, trusting that an interest may be created which will lead to some more definite action in the matter.

Perhaps the Institute of Actuaries might give the subject their attention; it certainly is one that may fairly challenge discussion, involving, as it does, considerations affecting all grades in the profession, from the actuary or secretary to the jumior clerk; and the adoption of some such scheme of superannuation as $I$ have sketched ont may not unfairly be considered as likely to influence the prosperity of such Companies as might be induced to entertain it; such a course being one that would appear to be eminently calculated to secure a continuance of the services of tried and efficient officers.

$$
\begin{aligned}
& \text { I am, } \mathrm{Sir}_{3} \\
& \text { Your obedient servant, }
\end{aligned}
$$

London, Jine, 1861. H. A.

[Nort.-The question of superannmation allowances by public institntions is one which we should be glad to see engage attention. The scheme recently adopted by the National Provineial Bank of England appears to be a very liberal one. This bank, moreover, several years ago, with the view to encourage provident habits among their employés, determined to pay onehalf of the yearly preminms of assurances on the lives of their officers and clerks. We may refer our readers to a letter on this subject, which will be found at page 72 , vol. v, of this Magazine. It is there suggested by a correspondent-Mr. Porter-that those engaged in life assurance, like those employed in all other descriptions of business, shonld be allowed to obtain the article in which their employers deal at cost price.-ED. A. M.] 